\title{
Trophic transfer of trace metals: subcellular compartmentalization in a polychaete and assimilation by a decapod crustacean
}

\author{
P. S. Rainbow ${ }^{1, *}$, L. Poirier $^{2}$, B. D. Smith ${ }^{1}$, K. V. Brix ${ }^{3,4}$, S. N. Luoma ${ }^{1,5}$ \\ ${ }^{1}$ Department of Zoology, The Natural History Museum, Cromwell Rd, London SW7 5BD, UK \\ ${ }^{2}$ Groupe Substances Marines à Activité Biologique (SMAB), UPRES EA 2160, Laboratoire d'Ecotoxicologie, \\ Université de Nantes, Pôle Mer et Littoral, BP 92208, 44322 Nantes Cedex 3, France \\ ${ }^{3}$ EcoTox, 590 Ocean Drive, No. 2C, Key Biscayne, Florida 33149, USA \\ ${ }^{4}$ RSMAS, University of Miami, 4600 Rickenbacker Causeway, Miami, Florida 33149, USA \\ ${ }^{5}$ United States Geological Survey, 345 Middlefield Road, Mail Stop 465, Menlo Park, California 94025, USA
}

\begin{abstract}
The chemical form of accumulated trace metal in prey is important in controlling the bioavailability of dietary metal to a predator. This study investigated the trophic transfer of radiolabelled Ag, Cd and $\mathrm{Zn}$ from the polychaete worm Nereis diversicolor to the decapod crustacean Palaemonetes varians. We used 2 populations of worms with different proportions of accumulated metals in different subcellular fractions as prey, and loaded the worms with radiolabelled metals either from sediment or from solution. Accumulated radiolabelled metals were fractionated into 5 components:metal-rich granules (MRG), cellular debris, organelles, metallothionein-like proteins (MTLP), and other (heat-sensitive) proteins (HSP). Assimilation efficiencies (AE) of the metals by $P$. varians were measured from the 4 categories of prey (i.e. 2 populations, radiolabelled from sediment or solution). There were significant differences for each metal between the AEs from the different prey categories, confirming that origin of prey and route of uptake of accumulated trace metal will cause intraspecific differences in subsequent metal assimilation. Correlations were sought between AEs and selected fractions or combinations of fractions of metals in the prey-MRG, Trophically Available Metal (TAM = MTLP + HSP + organelles) and total protein (MTLP + HSP). TAM explained $28 \%$ of the variance in AEs for Ag, but no consistent relationships emerged between AEs and TAM or total protein when the metals were considered separately. AEs did, however, show significant positive regressions with both TAM and total protein when the 3 metals were considered together, explaining only about $21 \%$ of the variance in each case. A significant negative relationship was observed between MRG and AE for all metals combined. The predator ( $P$. varians) can assimilate dietary metal from a range of the fractions binding metals in the prey ( $N$. diversicolor), with different assimilation efficiencies summated across these fractions. TAM and/or total protein may represent an approximate minimum for trophic availability but neither of these alone is a fully accurate predictor.
\end{abstract}

KEY WORDS: Trace metals · Trophic availability · Assimilation efficiency · Nereis diversicolor · Fractionation $\cdot$ Palaemonetes varians

\section{INTRODUCTION}

Aquatic invertebrates typically take up trace metals from both solution and their diet, and trophic transfer may often be the dominant uptake route (Wang 2002). As trophic transfer from prey to predators is coming under closer scrutiny, it is increasingly desirable to seek general principles governing the bioavailability of trace metals in the diet (Wallace \& Lopez 1996, 1997 , Munger \& Hare 1997, Wallace et al. 1998, Wallace \& Luoma 2003). The chemical form of detoxified metal stored in the prey organism is clearly one major factor controlling the assimilation of a trace metal by a predator (Wang \& Fisher 1999). 
Nott \& Nicolaidou (1990) showed that trace metals in detoxified metaliferous granules in barnacle and gastropod prey were more bioavailable to neogastropod predators when bound in carbonate granules rather than phosphate granules. In an investigation of the trophic transfer of metals from the digestive gland of 3 gastropod molluscs as prey tissue to the hermit crab Clibanarius erythropus, Nott \& Nicolaidou (1994) showed that the bioavailability of metals in the diet was affected by the nature of chemical binding during detoxificatory intracellular compartmentalization in the gastropod digestive glands. Metals in membranebound phosphate granules ( $\mathrm{Mn}, \mathrm{Ni}, \mathrm{Zn})$, lysosomes (also $\mathrm{Mn}, \mathrm{Ni}, \mathrm{Zn}$ ) and membrane-bound sulphur-rich granules $(\mathrm{Cu})$ were less bioavailable in the diet than cadmium associated with sulphur but free in the cytosol (Nott \& Nicolaidou 1994).

Similarly, the physicochemical form of accumulated cadmium in the oligochaete worm Limnodrilus hoffmeisteri was a major factor controlling the assimilation of cadmium by a predator, the decapod crustacean Palaemonetes pugio (Wallace \& Lopez 1996, 1997, Wallace et al. 1998). Cadmium in a population of cadmium-tolerant worms from Foundry Cove, Hudson River, New York was predominantly stored in trophically unavailable cadmium-rich granules. However, accumulated cadmium concentrations in these tolerant worms were so elevated that a greater absolute amount of cadmium was present in soluble form bound to the detoxificatory protein metallothionein (MT) (and therefore trophically available to the predator) than in non-resistant worms, despite the latter worms storing all their (lower concentration of) accumulated cadmium as MT (Wallace et al. 1998). An early proposal in the search for general principles controlling the bioavailability of trace metals in the diet was, therefore, that only metal bound to the soluble fraction in prey is available to higher trophic levels (Wallace \& Lopez 1996). Wallace \& Lopez (1997) then developed the concept, concluding that while Cd associated with cytosolic proteins in L. hoffmeisteri was $100 \%$ trophically available to $P$. pugio and $\mathrm{Cd}$ bound to metal-rich granules was unavailable, $\mathrm{Cd}$ bound to organelles was $70 \%$ trophically available.

Wallace \& Luoma (2003) progressed further, examining how the subcellular partitioning of $\mathrm{Cd}$ and $\mathrm{Zn}$ in the bivalves Macoma balthica and Potamocorbula amurensis affects the trophic transfer of these metals to the predatory decapod crustacean Palaemon macrodactylus. Wallace \& Luoma (2003) used the fractionation procedure of Wallace et al. (2003) to divide accumulated metals in the soft tissues of the bivalves into 5 components-metal-rich granules (MRG), cellular debris, organelles, metallothioneins (and MT-like proteins, MTLP), and other (heat-sensitive) proteins (HSP) presumed to consist mostly of enzymes. In partial agreement with Wallace \& Lopez (1997), Wallace \& Luoma (2003) could best explain their comparative assimilation results if trace metals bound to cell organelles were added to the 2 protein components to form the Trophically Available Metal fraction of metals (TAM) accumulated in the bivalve prey.

The present study describes the trophic transfer of the trace metals Ag, Cd and $\mathrm{Zn}$ accumulated by the polychaete worm Nereis diversicolor to the decapod crustacean predator Palaemonetes varians, in an attempt to test the applicability of the TAM of Wallace \& Luoma (2003) more widely as a general principle controlling trophic transfer in aquatic food chains. Advantage is taken of the availability of a copperand zinc-tolerant population of $N$. diversicolor from Restronguet Creek, Cornwall, UK (Bryan \& Hummerstone 1971, 1973, Grant et al. 1989, Hateley et al. 1989, Mouneyrac et al. 2003). These worms have well developed physiological systems to store excess accumulated trace metals, resulting in atypical proportions of accumulated metals in different detoxified subcellular components compared to worms from a control site, the Blackwater Estuary, Essex, UK (Berthet et al. 2003, Mouneyrac et al. 2003, Rainbow et al. 2004). Given the differences in the subcellular distributions of accumulated metals between the 2 field populations of $N$. diversicolor (Berthet et al. 2003, Mouneyrac et al. 2003, Rainbow et al. 2004), it was expected that the 2 populations of worms would show different subcellular distributions of radiolabelled metals after laboratory exposure, although it would indeed be unlikely that the subcellular distributions obtained would exactly match those of metals accumulated in the field over a much longer period. $N$. diversicolor from Restronguet Creek and the Blackwater Estuary were therefore radiolabelled with $\mathrm{Ag}, \mathrm{Cd}$ and $\mathrm{Zn}$ either via solution or sediment (from both of which $N$. diversicolor will accumulate metals, Bryan \& Hummerstone 1973) with the, intention of obtaining prey with different proportions of accumulated radiolabelled metals in the 5 fractions separable by the technique of Wallace et al. (2003). Subsets of worms were subjected to fractionation and the remainder fed to individual decapods ( $P$. varians) for the assessment of the assimilation efficiencies of the radiolabelled metals by the crustacean predator.

\section{MATERIALS AND METHODS}

Collection. Nereis diversicolor were collected by hand from intertidal mudflats (upper $20 \mathrm{~cm}$ sediment depth) in Restronguet Creek $\left(050^{\circ} 12.36^{\prime} \mathrm{N}\right.$, $\left.005^{\circ} 05.41^{\prime} \mathrm{W}\right)$ on 1 September 2003, 26 March 2004 and 28 July 2004, and in the Blackwater estuary 
$\left(051^{\circ} 44.08^{\prime} \mathrm{N}, 000^{\circ} 41.34^{\prime} \mathrm{E}\right)$ on 16 September 2003, 29 March 2004 and 27 July 2004, and transported back to the laboratory in cool boxes in sediment from the collection site. The worms were kept in sediment from the site of origin covered by artificial seawater (TM, Tropic Marin Tropicarium Buchschlag) at a salinity of 16 at $10^{\circ} \mathrm{C}$.

Palaemonetes varians were collected from salt marsh pools at Tollesbury, Blackwater estuary $\left(051^{\circ} 45.59^{\prime} \mathrm{N}\right.$, $000^{\circ} 50.08^{\prime} \mathrm{E}$ ) on 16 September 2003, 29 March 2004, 25 May 2004 and 27 July 2004, and transported back to the laboratory in cool boxes. The decapods were kept in aquaria in artificial seawater (TM) at a salinity of 6 at $10^{\circ} \mathrm{C}$. Adult $P$. varians of approximately equal size (about $3.5 \mathrm{~cm}$ total length) were used for experiments.

Radioisotopes. The radioactive tracer ${ }^{110 \mathrm{M}} \mathrm{Ag}$ was obtained from Riso National Laboratory, Denmark, ${ }^{109} \mathrm{Cd}$ from NEN Life Sciences Products, Boston, USA and ${ }^{65} \mathrm{Zn}$ from Brookhaven National Laboratory, New York, USA. Counts of live worms, dissected parts and isolated subcellular fractions of labelled worms, and live decapods were counted for contents of ${ }^{110 \mathrm{M}} \mathrm{Ag}$, ${ }^{109} \mathrm{Cd}$ and/or ${ }^{65} \mathrm{Zn}$ on an LKB Wallac 1480 Wizard counter. A standard was used in each analysis to determine the background radiation level and activity changes in the samples due to radioactive decay during the experimental periods. Because all 3 tracers are essentially carrier-free, negligible concentrations of total metal were added together with the tracers to either sediment or water (see following subsections).

Sediment: accumulation of radiolabelled metals by worms. Sediment collected from the site of worm collection in the Blackwater estuary in September 2003 was labelled with the radioactive tracers ${ }^{110 \mathrm{M}} \mathrm{Ag},{ }^{109} \mathrm{Cd}$ or ${ }^{65} \mathrm{Zn}$. Early experiments attempted simultaneous dual or triple labelling, but this was abandoned because the relative strength of the counts from one tracer (particularly Ag) at times swamped other counts (particularly Zn). Different relative accumulation rates of the radiolabelled metals by the worms also affected counting efficiencies of the different metals. Typically, $100 \mu \mathrm{Ci}$ of isotope was stirred into $100 \mathrm{ml} \mathrm{TM}$ (salinity 16). Each of two $50 \mathrm{ml}$ aliquots was then added with stirring to $100 \mathrm{~g}$ sediment in an acid-washed plastic box $(14 \times 8 \times 6 \mathrm{~cm})$ before being left to stand for $3 \mathrm{~d}$ at $10^{\circ} \mathrm{C}$. Further TM (salinity 16 ) was then added to each box to provide a depth of about $1 \mathrm{~cm}$ overlying the sediment, and 10 worms from either the Blackwater estuary or Restronguet Creek were added to each box and left for 14 to $21 \mathrm{~d}$ at $10^{\circ} \mathrm{C}$. Live worms were counted periodically to follow the accumulation of labelled metal before they were depurated in TM (salinity 16) for $2 \mathrm{~d}$ at $10^{\circ} \mathrm{C}$, and then frozen for later use in assimilation efficiency experiments. Regular counting of the water above the sediment indicated that the labelled metal remained sediment-bound and was not recycled into the water for subsequent uptake from solution by the worms.

Water: accumulation of zinc and cadmium from radiolabelled solution. We exposed 10 Nereis diversicolor from each site individually to radiolabelled Ag, $\mathrm{Cd}$ or $\mathrm{Zn}$ in solution. As in the case of the sediment labelling, early dual and triple labelling experiments suffered from differential strengths of counts and relative accumulation rates for the different metals, and later experiments mostly involved single labelling. Typically, labelling involved exposing worms $(0.25 \mu \mathrm{Ci}$ in $50 \mathrm{ml} \mathrm{TM}$, salinity 16) one by one in acid-washed $100 \mathrm{ml}$ beakers for 14 to $21 \mathrm{~d}$ at $10^{\circ} \mathrm{C}$. Each worm was counted live for radioactive $\mathrm{Ag}, \mathrm{Cd}$ or $\mathrm{Zn}$ before being frozen.

Assimilation efficiency. A pulse-chase feeding radiotracer technique was used to follow the assimilation of metals from the diet, according to the method of Wang \& Fisher (1999) and Wang \& Rainbow (2000). Radiolabelled worms were thawed, rinsed with nonlabelled TM for a few seconds, decapitated, counted, and cut into pieces approx. $5 \mathrm{~mm}$ long. The worms were counted in order to guarantee enough counts in the food to allow counting after ingestion. There was little variation in the radiolabelled metal concentrations of the different body pieces of individual worms, indicating that the different parts of the body behind the head were anatomically homogeneous with respect to metal accumulation.

Groups of prawns were fed with a piece of radiolabelled worm from 1 of 4 categories in a series of 4 separate experiments from December 2003 to August 2004 at $10^{\circ} \mathrm{C}$ in TM at 6 salinity: (1) Blackwater, sediment-labelled; (2) Blackwater, water-labelled; (3) Restronguet Creek, sediment-labelled; (4) Restronguet Creek, water-labelled. Not all experiments involved all 4 potential prey categories (see Table 1), varying according to the availability of prey worms with sufficient distinguishable counts of a particular metal. After the feeding period with radiolabelled worms, each prawn was rinsed with TM at salinity 6 and its radioactivity immediately counted for $60 \mathrm{~s}$. After counting, each prawn was returned to an individual container in clean 6 salinity $\mathrm{TM}$ at $10^{\circ} \mathrm{C}$ and fed regularly with Tetra Prima fish food (Tetra). Any faeces egested by the prawns were removed. The radioactivity in the prawns was monitored at frequent intervals (i.e. every $2 \mathrm{~h}$ ) during the first 8 to $12 \mathrm{~h}$ after feeding with radiolabelled worms, and at less frequent intervals (i.e. every 4 to $12 \mathrm{~h}$ ) thereafter for about $2 \mathrm{~d}$. Unlabelled water and food were renewed while the radioactivity of prawns was being counted.

Fractionation. We thawed 4 radiolabelled worms from each feeding regime, and after decapitation to 
ensure removal of their metal-rich jaws (Bryan \& Gibbs 1980), subjected them to the fractionation procedure of Wallace et al. (2003) and Wallace \& Luoma (2003). Briefly, the worms were homogenised on ice and centrifuged at $1450 \times g$ for $15 \mathrm{~min}$ at $4^{\circ} \mathrm{C}$. The pellet was treated with $1 \mathrm{M} \mathrm{NaOH}$ before further centrifugation $(5000 \times g, 10 \mathrm{~min})$ produced a pellet consisting of MRG and supernatant constituting cellular debris. The original supernatant was centrifuged at $100000 \times g$ for $1 \mathrm{~h}$ at $4^{\circ} \mathrm{C}$ to produce a pellet consisting of organelles, and a supernatant that was heat-treated $\left(80^{\circ} \mathrm{C}\right)$ before final centrifugation $(30000 \times g, 10 \mathrm{~min})$. The resulting pellet contained heat-sensitive proteins (mostly enzymes), and the supernatant held metallothioneins (or strictly metallothionein-like proteins) which are heat-stable. All fractions were counted for radiolabelled metal content.

Statistical analysis. Multiple replicates of the experiments were conducted to establish cross-experiment variance. Assimilation efficiency (AE) and fractionation percentage data were arcsine-transformed before statistical analysis by a priori analysis of variance (ANOVA) and post hoc a posteriori ANOVA using Tukey's HSD test for unequal numbers (Statistica).

\section{RESULTS}

\section{Assimilation efficiencies}

Fig. 1 shows the percentage retention of Ag by Palaemonetes varians feeding on Nereis diversicolor collected from either the Blackwater estuary or Restronguet Creek, and radiolabelled with Ag either

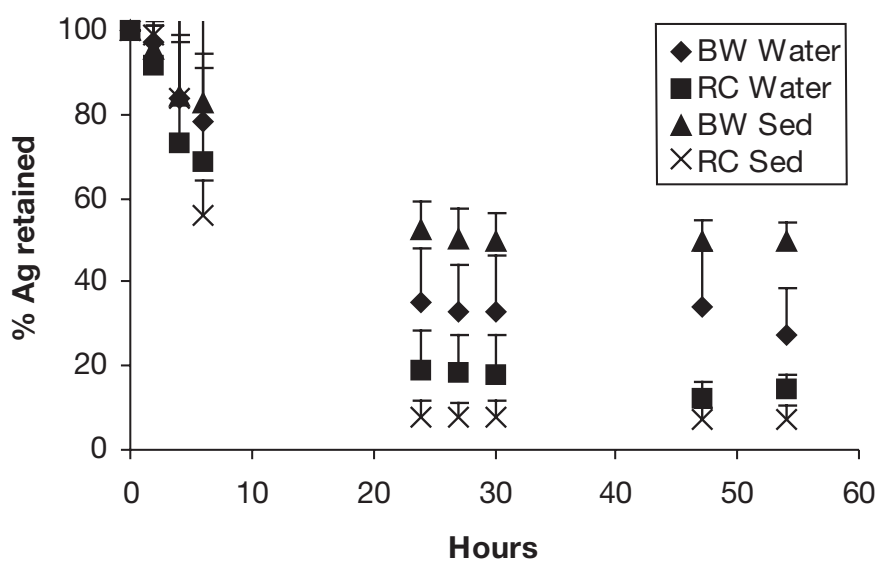

Fig. 1. Palaemonetes varians. Percentage (mean $+\mathrm{SD}, \mathrm{n}=5$ or 4) ingested Ag retained by the decapod crustacean feeding on the polychaete worm Nereis diversicolor collected from either the Blackwater estuary (BW) or Restronguet Creek (RC), and radiolabelled with Ag either from solution (Water) or sediment (Sed). Data set for June 2004 experiment from sediment or from solution, as measured in the experiment carried out in June 2004. The figure shows a typical pattern of the retention of ingested Ag. After the defaecation of unassimilated Ag (between 6 and $24 \mathrm{~h}$ after ingestion in this case) the retained percentage is the portion that has been assimilated by the decapod. This retained percentage is a measure of the AE (Wang \& Fisher 1999, Wang \& Rainbow 2000).

Table 1 presents AEs from all replicates of $\mathrm{Ag}, \mathrm{Cd}$ and $\mathrm{Zn}$ experiments. The time point (31 to $48 \mathrm{~h}$ ) at which the measured percentage retained was taken to be an estimate of the $\mathrm{AE}$, varied between experiments according to the starting times of the experiments themselves. In no case was there a significant change in this retained percentage between 24 and $96 \mathrm{~h}$ after ingestion, and any time point in this period could have sufficed as the point of measurement of the AE. Table 1 also presents the grand means of the data combined from the separate experiments. In each case we confirmed that there were no significant differences (ANOVA on arcsine-transformed percentage data, p > 0.05 ) between the results of the separate experiments before combination of the data.

A first question addressed in this study is whether there is any difference in the AE of a metal between diets. As also shown in Table 1, this is indeed the case for all 3 metals, as shown by statistical comparison (ANOVA on arcsine-transformed percentage data) of the grand mean percentage data.

In the case of silver, the AE from Blackwater worms labelled from sediment was significantly higher than for the other 3 diets (Table 1). In turn, the Ag AE from Blackwater worms labelled from water was significantly higher than the AEs from the 2 Restronguet Creek diets, which did not differ significantly (Table 1). The data set for the June 2004 experiment illustrates the order of the Ag AEs (Fig. 1).

For cadmium, there were again significant differences between the AEs from the different diets (Table 1). The highest Cd AE was in the case of the diet of Blackwater worms labelled from sediment, and the lowest from Blackwater worms labelled from water, with a significant difference between the two (Table 1). The $2 \mathrm{Cd}$ AEs from the Restronguet Creek worm diet did not differ significantly, nor did either differ significantly from either of the Blackwater worm diets (Table 1).

In the case of zinc, the AEs again showed significant differences between diets (Table 1). The Zn AE from the Restronguet Creek water-labelled diet was the highest, but was not significantly above that for the Blackwater water-labelled diet (Table 1). The Zn AE from Restronguet Creek sediment-labelled worms was significantly the lowest, with the Zn AE from the Blackwater sediment-labelled worms being intermediate (Table 1). 


\section{Fractionation}

Table 2 presents the data for each labelled trace metal obtained from the fractionation of the different categories of radiolabelled worms, the fractions being MRG, MTLP, cell debris, organelles and HSP. Also pre-

Table 1. Palaemonetes varians. Assimilation efficiencies (AE) of silver, cadmium and zinc of the decapod crustacean feeding on the polychaete worm Nereis diversicolor collected from either Blackwater estuary or Restronguet Creek, and radiolabelled with $\mathrm{Ag}, \mathrm{Cd}$ or $\mathrm{Zn}$ either from sediment or water, in up to 4 experiments from December 2003 to September 2004. Grand means with same superscript $\left({ }^{a},{ }^{b}, c\right)$ indicate that AEs for the relevant metal do not differ significantly (ANOVA on arcsine-transformed data)

\begin{tabular}{|c|c|c|c|c|c|c|}
\hline & \multicolumn{3}{|c|}{ Sediment } & \multicolumn{3}{|c|}{ Water } \\
\hline & Mean & SD & $\mathrm{n}$ & Mean & SD & $\mathrm{n}$ \\
\hline \multicolumn{7}{|l|}{ Ag } \\
\hline \multicolumn{7}{|c|}{ Blackwater estuary } \\
\hline Dec 2003 & & & & 34.6 & 7.4 & 9 \\
\hline Jan 2004 & 49.3 & 12.3 & 9 & 30.7 & 11.5 & 10 \\
\hline Jun & 49.6 & 5.4 & 5 & 33.9 & 13.6 & 5 \\
\hline Sep & 50.1 & 16.4 & 5 & 36.9 & 23.8 & 4 \\
\hline Grand mean & $49.6^{\mathrm{a}}$ & 11.6 & 19 & $33.4^{\mathrm{b}}$ & 12.5 & 28 \\
\hline \multicolumn{7}{|c|}{ Restronguet Creek } \\
\hline Dec 2003 & & & & 11.1 & 7.8 & 10 \\
\hline Jan 2004 & 20.0 & 12.9 & 10 & 10.0 & 5.5 & 10 \\
\hline Jun & 7.2 & 3.1 & 4 & 12.3 & 3.7 & 5 \\
\hline \multicolumn{7}{|l|}{ Sep } \\
\hline Grand mean & $16.9^{\mathrm{c}}$ & 12.2 & 14 & $10.9^{\mathrm{c}}$ & 6.1 & 25 \\
\hline \multicolumn{7}{|l|}{ Cd } \\
\hline \multicolumn{7}{|c|}{ Blackwater estuary } \\
\hline Jan 2004 & 63.0 & 15.9 & 7 & 34.5 & 11.3 & 6 \\
\hline Jun & 52.4 & 10.9 & 5 & 42.0 & 8.3 & 5 \\
\hline Sep & 57.7 & 21.7 & 4 & 41.0 & 14.1 & 4 \\
\hline Grand mean & $58.4^{\mathrm{a}}$ & 15.8 & 16 & $38.8^{\mathrm{b}}$ & 11.0 & 15 \\
\hline \multicolumn{7}{|c|}{ Restronguet Creek } \\
\hline Dec 2003 & & & & 52.3 & 12.2 & 7 \\
\hline Jan 2004 & & & & 43.7 & 15.9 & 6 \\
\hline Jun & 45.1 & 9.6 & 5 & & & \\
\hline Sep & 38.5 & 12.4 & 4 & 33.6 & 15.3 & 4 \\
\hline Grand mean & $42.1^{\mathrm{a}, \mathrm{b}}$ & 10.8 & 9 & $44.9^{\mathrm{a}, \mathrm{b}}$ & 15.4 & 17 \\
\hline \multicolumn{7}{|l|}{ Zn } \\
\hline \multicolumn{7}{|c|}{ Blackwater estuary } \\
\hline Dec 2003 & & & & 81.8 & 6.6 & 10 \\
\hline \multicolumn{7}{|l|}{ Jan 2004} \\
\hline Jun & 71.7 & 13.3 & 5 & 82.3 & 4.5 & 5 \\
\hline Sep & 74.2 & 7.5 & 4 & & & \\
\hline Grand mean & $72.8^{\mathrm{b}}$ & 10.5 & 9 & $82.0^{\mathrm{a}, \mathrm{b}}$ & 5.9 & 15 \\
\hline \multicolumn{7}{|c|}{ Restronguet Creek } \\
\hline Dec 2003 & & & & 84.1 & 8.8 & 8 \\
\hline Jan 2004 & & & & & & \\
\hline Jun & 41.3 & 11.7 & 5 & & & \\
\hline Sep & & & & & & \\
\hline Grand mean & $41.3^{\mathrm{c}}$ & 11.7 & 5 & $84.1^{\mathrm{a}}$ & 8.8 & 8 \\
\hline
\end{tabular}

sented in Table 2 are combinations of fractions, following Wallace et al. (2003) and Wallace \& Luoma (2003): biologically detoxified metal (BDM $=$ MRG + MTLP), metal sensitive fraction $(\mathrm{MSF}=$ organelles $+\mathrm{HSP})$ and Trophically Available Metal (TAM = MTLP + organelles + HSP). Additionally, another combination (total protein $=$ MTLP + HSP) is presented. All categories that include proteins (either MTLP or HSP) strictly refer to soluble proteins.

The largest single difference in partitioning among fractions was related to the detoxification of Ag, especially in the Restronguet Creek prey. The proportion of accumulated Ag distributed to the MRG overall (mean of $41.4 \%$ across the 4 treatments) was twice that of $\mathrm{Cd}$ and $\mathrm{Zn}$ (means of 20.3 and $17.3 \%$, respectively). There was also a lower percentage of Ag in MTLP than Cd (means of 10.6 vs. $27.0 \%$, respectively); but MTLP Ag was greater in Restronguet Creek individuals than in Blackwater individuals. There was less Ag in TAM than either $\mathrm{Cd}$ or $\mathrm{Zn}$ (means of $30.2 \%$ vs. 54.4 and $46.0 \%$ respectively across the 4 treatments).

There were significant differences between the prey worm categories in the percentage distributions of accumulated radiolabelled $\mathrm{Cd}$ bound to total protein, and in the percentage distributions of radiolabelled $\mathrm{Zn}$ to both TAM and total protein (Table 2). There were, however, no significant differences between prey categories in the percentage distributions of $\mathrm{Ag}$ into either TAM or total protein, or for $\mathrm{Cd}$ bound to TAM (Table 2). Blackwater prey had much higher Zn in total protein than Restronguet Creek prey, and they had more Zn as TAM (Table 2).

\section{Correlations}

Table 3 gives regression details for possible relationships between assimilation efficiencies of Palaemonetes varians for the 3 trace metals (individually and combined) and the percentages of accumulated radiolabelled metal in the worm prey present as MRG, TAM or total protein. The Ag AE was significantly ( $p<$ 0.001) positively related to the percentage of prey Ag present as TAM (Fig. 2), but there was no significant regression for $\mathrm{Zn}$, and the regression for Cd was significantly negative (Table 3). Ag AE showed a significant negative relationship with total protein, but there was no significant relationship with total protein for either $\mathrm{Cd} \mathrm{AE}$ or $\mathrm{Zn} \mathrm{AE}$. For the 3 metals combined, there was a significant positive regression of $\mathrm{AE}$ against the percentage of accumulated radiolabelled metal in the worm prey present as both TAM and total protein (Table 3, Fig. 2). There were significant negative regressions between the percentage of accumulated radiolabelled metal in the form of MRG and AE for Ag, 
Table 2. Nereis diversicolor. Percentage distributions (mean $\pm \mathrm{SD}, \mathrm{n}=4$ ) of silver, cadmium and zinc in 5 different fractions and combinations of these fractions (after Wallace \& Luoma 2003, Wallace et al. 2003) of polychaete worms collected from either Blackwater estuary or Restronguet Creek, and radiolabelled with Ag, Cd or Zn either from sediment or water. Fractions are metal-rich granules (MRG), metallothionein-like proteins (MTLP), cell debris, organelles and heat-sensitive proteins (HSP); combinations are biologically detoxified metal $(\mathrm{BDM}=\mathrm{MRG}+\mathrm{MTLP})$, metal-sensitive fraction $(\mathrm{MSF}=$ organelles + HSP), Trophically Available Metal $\left(\right.$ TAM = MTLP + organelles + HSP), and total protein (MTLP + HSP). Means with same superscript $\left({ }^{a}, b\right)$ within a column indicate that percentages of accumulated radiolabelled metal present as MRG, TAM or total protein do not differ significantly (ANOVA on arcsine-transformed data) for the relevant metal

\begin{tabular}{|c|c|c|c|c|c|c|c|c|c|}
\hline & MRG & MTLP & Cell debris & Organelles & HSP & $\mathrm{BDM}$ & MSF & TAM & Total protein \\
\hline \multicolumn{10}{|l|}{ Ag } \\
\hline \multicolumn{10}{|c|}{ Blackwater estuary } \\
\hline Sediment & $35.6 \pm 3.6$ & $8.6 \pm 5.4$ & $28.0 \pm 11.0$ & $23.8 \pm 7.9$ & $3.9 \pm 2.5$ & $44.2 \pm 5.8$ & $27.8 \pm 8.7$ & $36.4^{\mathrm{a}} \pm 12.9$ & $12.6^{\mathrm{a}} \pm 5.8$ \\
\hline Water & $37.3 \pm 13.9$ & $4.7 \pm 2.9$ & $35.8 \pm 10.3$ & $20.1 \pm 12.6$ & $2.0 \pm 1.6$ & $42.1 \pm 12.1$ & $22.1 \pm 11.4$ & $26.8^{\mathrm{a}} \pm 13.4$ & $6.8^{\mathrm{a}} \pm 1.7$ \\
\hline \multicolumn{10}{|c|}{ Restronguet Creek } \\
\hline Sediment & $45.1 \pm 15.5$ & $17.7 \pm 7.4$ & $33.3 \pm 11.8$ & $10.6 \pm 2.9$ & $5.5 \pm 5.6$ & $50.6 \pm 13.2$ & $16.1 \pm 7.4$ & $33.8^{\mathrm{a}} \pm 13.4$ & $23.2^{\mathrm{a}} \pm 10.7$ \\
\hline Water & $47.6 \pm 12.3$ & $11.2 \pm 9.2$ & $37.5 \pm 11.0$ & $10.3 \pm 4.9$ & $2.3 \pm 0.6$ & $49.9 \pm 12.7$ & $12.6 \pm 4.0$ & $23.7^{\mathrm{a}} \pm 14.2$ & $13.5^{\mathrm{a}} \pm 9.5$ \\
\hline \multicolumn{10}{|l|}{ Cd } \\
\hline \multicolumn{10}{|l|}{ Blackwater } \\
\hline Sediment & $18.6 \pm 4.5$ & $26.0 \pm 10.4$ & $39.9 \pm 10.0$ & $16.2 \pm 1.0$ & $5.6 \pm 6.2$ & $42.6 \pm 12.0$ & $22.0 \pm 7.3$ & $47.9^{\mathrm{a}} \pm 5.3$ & $31.6^{\mathrm{a}, \mathrm{b}} \pm 5.6$ \\
\hline Water & $20.9 \pm 3.3$ & $31.7 \pm 4.2$ & $23.4 \pm 2.3$ & $22.2 \pm 2.2$ & $1.9 \pm 0.5$ & $52.5 \pm 3.3$ & $24.1 \pm 2.1$ & $55.8^{\mathrm{a}} \pm 4.6$ & $33.6^{\mathrm{a}} \pm 4.7$ \\
\hline \multicolumn{10}{|c|}{ Restronguet Creek } \\
\hline Sediment & $22.4 \pm 8.9$ & $19.3 \pm 8.7$ & $19.5 \pm 1.8$ & $37.6 \pm 6.3$ & $1.2 \pm 0.5$ & $41.7 \pm 6.6$ & $38.8 \pm 5.9$ & $58.1^{\mathrm{a}} \pm 9.3$ & $20.5^{\mathrm{b}} \pm 9.1$ \\
\hline Water & $19.2 \pm 3.1$ & $31.1 \pm 2.4$ & $25.1 \pm 1.3$ & $23.1 \pm 1.9$ & $1.5 \pm 0.2$ & $50.3 \pm 1.1$ & $24.6 \pm 1.8$ & $55.7^{\mathrm{a}} \pm 3.3$ & $32.6^{\mathrm{a}, \mathrm{b}} \pm 2.5$ \\
\hline \multicolumn{10}{|l|}{$\mathrm{Zn}$} \\
\hline \multicolumn{10}{|l|}{ Blackwater } \\
\hline Sediment & $8.4^{b} \pm 2.4$ & $38.6 \pm 2.5$ & $29.2 \pm 4.6$ & $7.8 \pm 2.8$ & $16.0 \pm 2.7$ & $47.0 \pm 2.3$ & $23.8 \pm 2.4$ & $62.4^{\mathrm{a}} \pm 4.7$ & $54.6^{\mathrm{a}} \pm 4.8$ \\
\hline Water & $6.8^{\mathrm{b}} \pm 3.0$ & $24.0 \pm 16.9$ & $43.9 \pm 11.2$ & $3.3 \pm 1.8$ & $22.0 \pm 8.3$ & $30.8 \pm 15.1$ & $25.2 \pm 7.7$ & $49.3^{\mathrm{a}, \mathrm{b}} \pm 12.2$ & $46.0^{\mathrm{a}} \pm 10.7$ \\
\hline \multicolumn{10}{|c|}{ Restronguet Creek } \\
\hline Sediment & $16.8^{\mathrm{a}, \mathrm{b}} \pm 2.5$ & $3.8 \pm 2.0$ & $35.2 \pm 3.7$ & $32.6 \pm 6.2$ & $7.7 \pm 4.7$ & $24.5 \pm 3.7$ & $40.3 \pm 2.0$ & $44.1^{\mathrm{a}, \mathrm{b}} \pm 3.2$ & $11.5^{\mathrm{b}} \pm 5.8$ \\
\hline Water & $37.0^{\mathrm{a}} \pm 25.0$ & $4.7 \pm 3.7$ & $36.5 \pm 10.3$ & $20.6 \pm 10.5$ & $2.9 \pm 3.1$ & $39.9 \pm 22.2$ & $23.5 \pm 13.3$ & $28.2^{\mathrm{b}} \pm 16.0$ & $7.6^{\mathrm{b}} \pm 5.7$ \\
\hline
\end{tabular}

Table 3. Palaemonetes varians. Regression details for relationships between trace metal assimilation efficiency $\mathrm{AE}(y)$ and percentages $(x)$ of accumulated radiolabelled metals present in metal-rich granules (MRG) fraction and combined fractions TAM and total protein (see 'Results' for details); ns = not significant

\begin{tabular}{|lllll|}
\hline & \multicolumn{1}{c}{ Equation } & adj $\mathrm{R}^{2}$ & $\mathrm{n}$ & $\mathrm{p}$ \\
\hline Silver & & & & \\
Ag AE vs. Ag TAM & $y=1.922 x-28.30$ & 0.280 & 86 & $<0.001$ \\
Ag AE vs. Ag total protein & $y=-1.150 x+42.35$ & 0.109 & 86 & $<0.01$ \\
Ag AE vs. Ag MRG & $y=-2.761 x+141.5$ & 0.606 & 86 & $<0.001$ \\
Cadmium & & & & \\
Cd AE vs. Cd TAM & $y=-1.868 x+147.3$ & 0.204 & 57 & $<0.001$ \\
Cd AE vs. Cd total protein & $y=0.160 x+41.72$ & 0.016 & 57 & $0.732 \mathrm{~ns}$ \\
Cd AE vs. Cd MRG & $y=-4.167 x+129.9$ & 0.121 & 57 & $<0.01$ \\
Zinc & & & & \\
Zn AE vs. Zn TAM & $y=-0.186 x+83.49$ & 0.010 & 37 & $0.424 \mathrm{~ns}$ \\
Zn AE vs. Zn total protein & $y=0.194 x+67.87$ & 0.028 & 37 & $0.161 \mathrm{~ns}$ \\
Zn AE vs. Zn MRG & $y=0.109 x+73.07$ & 0.022 & 37 & $0.635 \mathrm{~ns}$ \\
All 3 metals & & & & \\
AE vs. TAM & $y=0.875 x+7.760$ & 0.214 & 180 & $<0.001$ \\
AE vs. total protein & $y=0.823 x+24.45$ & 0.217 & 180 & $<0.001$ \\
AE vs. MRG & $y=-1.250 x+79.75$ & 0.458 & 180 & $<0.001$ \\
\hline
\end{tabular}

Cd and for all 3 metals combined (Table 3, Fig. 2). It should be recognised that the significant regressions observed (Fig. 2, Table 3) do not take into account the variation about the estimated values for the percentages of accumulated metal in the MRG, TAM and total protein fractions (single values of $x$ for multiple values of $y$ in the regression equations).

\section{DISCUSSION}

A novel aspect of this study has been the comparison of dietary bioaccumulation by a predator from 2 populations of a prey species (Nereis diversicolor) with different exposure histories. Many of the estuaries of SW England remain contaminated with metals in sediments as a result of a long legacy of mining activities (most intensively in the 19th century) in 

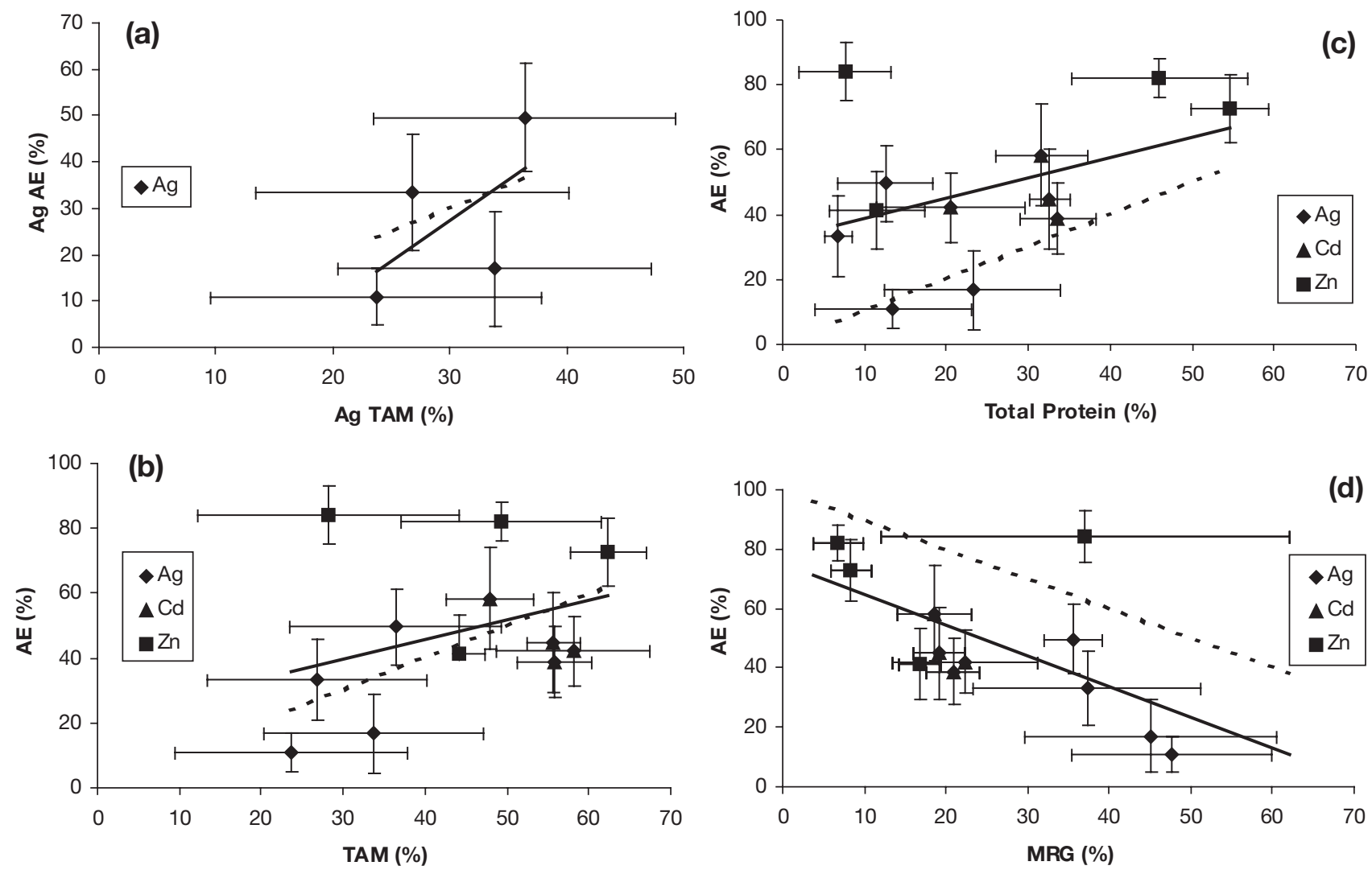

Fig. 2. Palaemonetes varians feeding on Nereis diversicolor. Regressions between (a) assimilation efficiency Ag (AE) of P. varians and percentage accumulated radiolabelled Ag present in TAM fraction in prey, (b) AE and percentage of accumulated radiolabelled metal present in the TAM fraction in prey for Ag, Cd and Zn combined, (c) AE and percentage of accumulated radiolabelled metal present in total protein fraction, and (d) AE and percentage of accumulated radiolabelled metal present in metalrich granules (MRG) fraction. Details of best-fit least-squares regressions (solid lines), weighted by different numbers in each data set, are given in Table 3. Dashed lines indicate 1:1 relationship (inverse for d). Data are means \pm 1 SD

Devon and Cornwall. The long-term effects of this sediment contamination are not well known. Potential effects on predators from metal-contaminated invertebrates in the contaminated water bodies are of particular concern. Dietary transfer of metals from prey to predator is now well known to be significant (e.g. Wang 2002). Where a long legacy of metal contamination exists, some invertebrate species may adapt via selection of detoxification capabilities. Effects of such detoxification processes on trophic transfer of metals are not well known. In this case we have determined trophic transfer to a shrimp from a polychaete species resident in an estuary where sediments have been heavily contaminated with metals for a century or more. We have compared that to trophic transfer from a population of $N$. diversicolor with much less exposure to metal contamination. The polychaetes from Restronguet Creek were metal tolerant in the 1970s (Bryan \& Hummerstone 1971, 1973), and retain that tolerance (Mouneyrac et al. 2003). In nature, tolerance in $N$. diversicolor from Restronguet Creek (as com- pared to the Blackwater estuary) is reflected in different percentages of accumulated trace metals in different subcellular compartments (Berthet et al. 2003, Mouneyrac et al. 2003, Rainbow et al. 2004). Metalrich granules are an important pathway of detoxification in the polychaetes from Restronguet Creek. For example, the major detoxified store of $\mathrm{Zn}$ (but not $\mathrm{Cd}$ ) in worms from Restronguet Creek was in spherocrystals in cells of the gut wall; the same spherocrystals occur in the Blackwater worms, but are less abundant and do not contain elevated concentrations of $\mathrm{Zn}$ (Mouneyrac et al. 2003). To compare the influences of the population differences on metal trophic availability, we concentrated attention on the 3 least ambiguous fractions or combinations of fractions that might be predictive. The proportion of metal bound in metalrich granules is likely to be relatively unavailable for trophic transfer (Nott \& Nicolaudou 1990). The proposed TAM fraction of Wallace \& Luoma (2003) and the total protein fraction (Reinfelder \& Fisher 1992) have been related to dietary bioaccumulation in previous 
studies. Total protein is equivalent to the metal fraction bound to cytosolic proteins as defined by Wallace \& Lopez $(1996,1997)$.

Metals from both populations of polychaetes were bioavailable to the shrimp via the diet. In general, assimilation efficiencies from polychaetes to shrimp were as high or higher than typically observed at lower trophic levels (e.g. sediment or phytoplankton to polychaetes or bivalves; Wang 2002). In metal-contaminated estuaries, therefore, it is likely that $\mathrm{Ag}, \mathrm{Cd}$ and Zn concentrated in the sediments are subsequently passed to predators in proportion to their concentration in their benthic prey. The questions addressed here were how variable is this transfer among metals and between estuaries, and is trophic transfer affected by exposure history or route of uptake?

There were significant differences in the assimilation efficiencies of Palaemonetes varians for all 3 metals between the 4 categories of prey, i.e. Nereis diversicolor from either the Blackwater estuary or Restronguet Creek, radiolabelled either from the sediment or from solution (Table 1). The route of exposure used to label the prey appeared to have less effect on either fractionation or assimilation by the predator than metal or site of collection. Origin of prey did cause some differences in assimilation efficiency of the predator.

When each metal is considered alone, exposure history of the prey appeared to have affected Ag bioavailability. The AEs of Ag from the 2 Blackwater worm diets were significantly higher than for either of the 2 Restronguet Creek worm diets. The statistically significant differences in $\mathrm{AEs}$ of $\mathrm{Cd}$ and $\mathrm{Zn}$ did not follow exposure history alone. For Cd, the Blackwater worms yielded the highest and lowest AEs (differing significantly from each other), but the AEs from the Restronguet Creek worms were not significantly different from either of the Blackwater AEs. For Zn, the highest AE was from the water-labelled Restronguet Creek worms, and the significantly lowest AE was from the sediment-labelled Restronguet Creek worms.

Exposure history in the different estuaries had variable impacts on the different proportions of accumulated metal in different subcellular fractions of Nereis diversicolor. The proportions of accumulated Ag and $\mathrm{Cd}$ in the form of MRG did not differ significantly between the worm populations, although Ag-rich granules were slightly more abundant in Restronguet Creek worms (Table 2). On the other hand, the proportion of accumulated zinc in MRG was significantly higher in the Restronguet Creek worms (Table 2), as found for stable metals in this population (Mouneyrac et al. 2003)

There was no statistically significant influence of estuary of origin, or exposure route in the percentages of accumulated radiolabelled Ag present as either TAM or total protein, but differences were seen in the cases of $\mathrm{Cd}$ and Zn (Table 2). There was a significant difference between the 4 groups of prey worms in the distribution of radiolabelled $\mathrm{Cd}$ into total protein, but not into TAM. Water-labelled Blackwater worms had the most $\mathrm{Cd}$ bound to total protein, but only significantly more than 1 other category, the sediment-labelled Restronguet Creek worms (Table 2). More differences were apparent for Zn. Restronguet Creek worms radiolabelled from water had the lowest percentages of accumulated labelled $\mathrm{Zn}$ in both TAM and total protein fractions, while sediment-labelled Blackwater worms had the highest percentages in both these fractions (Table 2).

Fractionation of the radiolabel differed from fractionation of stable metals in the 2 populations, reflecting the difficulty of uniformly labelling long-lived prey collected from the field. Previous studies of dietary bioaccumulation have often used phytoplankton as the food source. Uniformly labelling a growing population of phytoplankton is relatively straightforward (Wang \& Fisher 1999). Comparisons to nature show, however, that Nereis diversicolor from the Blackwater estuary and Restronguet Creek were probably not uniformly labelled. The percentages of accumulated stable $\mathrm{Cd}$ and $\mathrm{Zn}$ in the different subcellular compartments differed from those determined in earlier studies (Berthet et al. 2003, Mouneyrac et al. 2003). In nature, worms from Restronguet Creek held 51 and $81 \%$ of body Cd and $\mathrm{Zn}$ respectively in soluble form, while Blackwater worms had $72 \%$ of body $\mathrm{Cd}$ and $68 \%$ of body $\mathrm{Zn}$ in the soluble fraction (Berthet et al. 2003). The radiolabelled worms from Restronguet Creek had 21 to $33 \% \mathrm{Cd}$ and 8 to $12 \% \mathrm{Zn}$ in soluble form, compared with 32 to $34 \%$ $\mathrm{Cd}$ and 46 to $55 \% \mathrm{Zn}$ for worms from the Blackwater estuary. Soluble Cd and Zn were proportionately lower in Restronguet Creek in most (but not all) cases. The stable metals were accumulated over a long period and potentially from both solution and local sediment. The radiolabelled fractions simulate a short-term exposure, resulting in the different proportional distribution. The different percentages for 'old' and 'new' accumulated $\mathrm{Cd}$ and $\mathrm{Zn}$ presumably reflect the difference between short-term and lifelong influences on the different dynamic aspects of the physiological detoxification and storage processes in the worms.

The relationships among feeding route, metal and site of origin are complex when fractionation and $\mathrm{AE}$ are compared. Silver showed clear differences in AEs of ingested labelled metals between prey categories, and yet there were no significant differences between percentage distributions of labelled Ag in either TAM or total protein combined fractions. Linear regression, however, showed a significant relationship between AEs measured in individual Palaemonetes varians and 
the percentage of accumulated labelled Ag in the TAM fraction of the worm prey, explaining $28 \%$ of the variance (Table 3, Fig. 2). Otherwise, relationships with TAM and total protein for each metal alone were either insignificant or of questionable meaning (negative).

Previous studies have found the strongest relationships between metal form in prey and assimilation by consumer or predator by comparing across metals. The greatest differences in $\mathrm{AE}$ and fractionation were also found among metals in our experiment (a smaller proportion of Ag than Cd in TAM and total protein, with Zn more variable). When the data sets for the 3 metals were combined in a regression, a clearer picture emerged (Fig. 2). Assimilation efficiency was positively correlated with the percentage distribution of metal accumulated by prey in both the TAM and total protein fractions. These 2 combined fractions broadly explain why bioavailability to predators differs, especially among metals. The strong negative relationship of $\mathrm{AE}$ with the proportion of accumulated metal in the form of metal-rich granules indicates that prey that use this process for detoxifying metals may be a lesser source of trophic metal transfer than those which detoxify primarily with soluble metal-specific binding proteins. Thus, the fractionation of accumulated metal in prey does contribute to the processes that determine metalspecific differences in $\mathrm{AE}$ to a greater extent than the more subtle differences among populations or exposure routes of prey within each metal.

While the regressions were significant, the relationships were quite variable, explaining only about $21 \%$ of the variance in the case of TAM and total protein (Table 3); the inverse relationship in the case of the metal-rich granules explained more $(46 \%)$ of the variance. The distribution of the data and the relationship of the data to a theoretical 1:1 relationship were also informative. The shape of the data distribution (see Fig. 2) suggests that a high percentage of TAM never coincides with the lowest AEs; although high AEs can occur at lowest proportions of TAM or total protein. This type of data distribution (termed a 'factor ceiling effect'; Cade \& Noon 2003) is typical of environmental data where more than 1 independent variable influences the variance in the dependent variable. The most important observation is that at low TAM or total protein percentages, other fractions appear to contribute to bioavailability. This is also reflected in the positioning of the data (i.e. the intercept). A 1:1 relationship between metal AE in a consumer and soluble metal in phytoplankton has been reported previously (Reinfelder \& Fisher 1991). Where that relationship was not observed, less metal than expected was often assimilated (Lee \& Luoma 1998). In this study, the relationship between TAM and AE largely corresponded to the $1: 1$ relationship, with 2 strong positively deviant points. The data for the total protein relationship fell largely above the 1:1 relationship, indicating that some metal outside the total protein fraction was bioavailable. It is clear that total protein does not fully define the fraction of metal passed from Nereis diversicolor to its predator. It also appears that some metal from fractions outside TAM is bioavailable.

A plausible conclusion from the results, therefore, is that Palaemonetes varians assimilates metal from a range of the fractions binding metals in the prey, with different assimilation efficiencies summated across these fractions. The presence of granules appears to be highly influential in reducing trophic transfer. This would be in accord with the conclusions of Nott \& Nicolaidou (1990, 1994) and Wallace \& Lopez (1997). Different subcellular components binding metals in prey organisms are trophically available to a predator to different extents. The trophic availabilities of the different components would also vary according to the digestive physiology of different predators. Correspondingly, it is probably not possible, with these relatively crude operational fractionations, to define unequivocally an exact trophically available metal fraction that is of wide applicability across predators and prey species, especially for individual metals. The processes that differentiate tolerance in different populations may also be difficult to capture with fractionation; especially, again, within metals. The TAM fraction will probably best differentiate only large differences in bioavailability or, at best, identify potential instances of high bioavailability from a prey. For example, Wallace \& Luoma (2003) used TAM to explain the case of the Cd bioaccumulation by the decapod crustaceans Palaemon macrodactylus and P. pugio feeding across a range of prey types from bivalve tissue to $\mathrm{Cd}$ tolerant oligochaetes. TAM provided the best explanation in the present study when the 3 metals were considered in combination, but still explained only a little more than $20 \%$ of the variance observed. Metals bound to the 3 components of the TAM (metallothioneins, other proteins and organelles) of Wallace \& Luoma (2003) probably figure strongly as the more trophically available fractions of accumulated metals in the prey organisms in many predator-prey relationships, but with different AEs for the different fractions according to their exact chemical nature and the digestive physiology of the predator. Directly identifying any insoluble detoxified storage forms may also be useful, because their abundance can differ widely among potential prey like bivalves and polychaetes such as Nereis diversicolor (Marigomez et al. 2002, Mouneyrac et al. 2003, Rainbow et al. 2004).

It is therefore concluded that the predator Palaemonetes varians can assimilate dietary metal from a range of the fractions binding metals in the prey Nereis 
diversicolor, with different assimilation efficiencies summated across these fractions. TAM and/or total protein may represent an approximate minimum for trophic availability but neither of these alone is a fully accurate predictor.

Acknowledgements. This research was partly supported by funding from the International Lead Zinc Research Organization and Rio Tinto. S.N.L.'s contribution was partly funded by a WJ Fulbright Distinguished Scholar Award.

\section{LITERATURE CITED}

Berthet B, Mouneyrac C, Amiard JC, Amiard-Triquet C and 5 others (2003) Responses to metals of the polychaete annelid Hediste diversicolor, a key species in estuarine and coastal sediments. Arch Environ Contam Toxicol 45: $468-478$

Bryan GW, Gibbs PE (1980) Metals in nereid polychaetes: the contribution of metals in the jaws to the total body burden. J Mar Biol Assoc UK 60:641-654

Bryan GW, Hummerstone LG (1971) Adaptation of the polychaete Nereis diversicolor to estuarine sediments containing high concentrations of heavy metals. I. General observations and adaptation to copper. J Mar Biol Assoc UK 51:845-863

Bryan GW, Hummerstone LG (1973) Adaptation of the polychaete Nereis diversicolor to estuarine sediments containing high concentrations of zinc and cadmium. J Mar Biol Assoc UK 53:839-857

Cade BS, Noon BR (2003) A gentle introduction to quantile regression for ecologists. Front Ecol Environ 1:412-420

Grant A, Hateley JG, Jones NV (1989) Mapping the ecological impact of heavy metals in the estuarine polychaete Nereis diversicolor using inherited metal tolerance. Mar Pollut Bull 20:235-238

Hateley JG, Grant A, Jones NV (1989) Heavy metal tolerance in estuarine populations of Nereis diversicolor. In: Ryland JS, Tyler PA (eds) Reproduction, genetics and distribution of marine organisms. Proc 23rd Eur Mar Biol Symp. Olsen and Olsen, Fredensborg, p 379-385

Lee BG, Luoma SN (1998) Influence of microalgal biomass on absorption efficiency of $\mathrm{Cd}, \mathrm{Cr}$, and $\mathrm{Zn}$ by two bivalves from San Francisco Bay. Limnol Oceanogr 43: 1455-1466

Marigomez I, Soto M, Carajaville MP, Angulo E, Giamberini

Editorial responsibility: Otto Kinne (Editor-in-Chief), Oldendorf/Luhe, Germany
L (2002) Cellular and subcellular distribution of metals in mollusks. Microsc Res Techn 56:358-392

Mouneyrac C, Mastain O, Amiard JC, Amiard-Triquet C, Beaunier P, Jeantet AY, Smith BD, Rainbow PS (2003) Trace-metal detoxification and tolerance of the estuarine worm Hediste diversicolor chronically exposed in their environment. Mar Biol 143:731-744

Munger C, Hare L (1997) Relative importance of water and food as cadmium sources to an aquatic insect (Chaoborus punctipennis): implications for predicting Cd bioaccumulation in nature. Environ Sci Technol 31:891-895

Nott JA, Nicolaidou A (1990) Transfer of metal detoxification along marine food chains. J Mar Biol Assoc UK 70: 905-912

Nott JA, Nicolaidou A (1994) Variable transfer of detoxified metals from snails to hermit crabs in marine food chains. Mar Biol 120:369-377

Rainbow PS, Geffard A, Jeantet AY, Smith BD, Amiard JC, Amiard-Triquet C (2004) Enhanced food-chain transfer of copper from a diet of copper-tolerant estuarine worms. Mar Ecol Prog Ser 271:183-191

Reinfelder JR, Fisher NS (1991) The assimilation of elements ingested by marine copepods. Science 251:794-796

Wallace WG, Lopez GR (1996) Relationship between the subcellular cadmium distribution in prey and cadmium transfer to a predator. Estuaries 19:923-930

Wallace WG, Lopez GR (1997) Bioavailability of biologically sequestered cadmium and the implications of metal detoxification. Mar Ecol Prog Ser 147:149-157

Wallace WG, Luoma SN (2003) Subcellular compartmentalization of $\mathrm{Cd}$ and $\mathrm{Zn}$ in two bivalves. II. The significance of trophically available metal (TAM). Mar Ecol Prog Ser 257:125-137

Wallace WG, Lopez GR, Levington JS (1998) Cadmium resistance in an oligochaete and its effect on cadmium trophic transfer to an omnivorous shrimp. Mar Ecol Prog Ser 172: $225-237$

Wallace WG, Lee BG, Luoma SN (2003) Subcellular compartmentalization of $\mathrm{Cd}$ and $\mathrm{Zn}$ in two bivalves. I. Significance of metal-sensitive fractions (MSF) and biologically detoxified metal (BDM). Mar Ecol Prog Ser 249:183-197

Wang WX (2002) Interactions of trace metals and different marine food chains. Mar Ecol Prog Ser 243:295-309

Wang WX, Fisher NS (1999) Assimilation efficiencies of chemical contaminants in aquatic invertebrates: a synthesis. Environ Toxicol Chem 18:2034-2045

Wang WX, Rainbow PS (2000) Dietary uptake of Cd, Cr, and $\mathrm{Zn}$ by the barnacle Balanus trigonus: influence of diet composition. Mar Ecol Prog Ser 204:159-168

Submitted: January 28, 2005; Accepted: July 19, 2005

Proofs received from author(s): January 20, 2006 